\title{
Awareness and knowledge of glaucoma among hospital personnel in a tertiary care center in rural Karnataka
}

\author{
Padmajothi M.S. ${ }^{1}$, Chaitra M. C. ${ }^{2}$, Anneshi R.C. ${ }^{3}$ \\ ${ }^{1}$ Dr. M. S. Padmajothi, Professor, ${ }^{2}$ Dr. Chaitra M. C., Assistant Professor, ${ }^{3}$ Dr. Anneshi R.C., Post Graduate, all authors \\ are affiliated with Department of Ophthalmology, Sri Devaraj Urs Medical College, Tamaka, Kolar, Karnataka, India.
}

Corresponding Author: Dr. Chaitra M. C., Assistant Professor, Department of Ophthalmology, Sri Devaraj Urs Medical College, Tamaka, Kolar.No. 109, HSR Grand Apartment, Doddabanaswadi Main Road, Near Baldwin's School, Banaswadi, Bangalore, India. Email: drchaitramc@gmail.com

\begin{abstract}
Purpose: To evaluate the awareness and knowledge of Glaucoma among hospital personnel. Methods: A Crosssectional study was conducted in the hospital consisting of medical and non-medical staff excluding those who have already undergone treatment for Glaucoma. After taking an informed consent, a self-designed questionnaire was administered. Results: 513 people participated in the study with mean age of participants being 34.36+/-5.686 year. Although $95 \%$ were aware of Glaucoma, the awareness of causes and treatment of Glaucoma were high only among the clinicians (88\%) \& very poor (28\%) among nursing \& administrative staff. $41 \%$ were aware that glaucoma can lead to blindness. Conclusion: The study revealed unsatisfactory knowledge concerning glaucoma among health personnel. This alarming revelation warrants the need for enrichment of glaucoma awareness programs.
\end{abstract}

Keywords: Glaucoma, Awareness, Knowledge, Hospital personnel.

\section{Introduction}

The leading cause for irreversible blindness worldwide is Glaucoma, the silent thief of sight [1]. It is estimated to affect over 11 million Indians [2]. By 2020, India has been projected to be the second largest home of glaucoma cases [3]. Early detection of Open Angle Glaucoma (OAG) is difficult due to its asymptomatic course in the early stages. Many a time Closed Angle Glaucoma patient also do not report to the ophthalmologist in the early stages. Many literatures have shown that $50-90 \%$ of the Glaucoma cases remain undiagnosed [4] and a large number of cases are diagnosed at a later stage of the disease [5].

Importance of early diagnosis of Glaucoma cannot be underestimated, for its effective treatment and prevention of blindness. Lack of awareness regarding Glaucoma is an important reason for its late presentation, which significantly increases the risk of blindness. Not only does the lack of awareness influence the timing of the diagnosis, but also the utilization of eye care services. Therefore, assessment of awareness should be the first step in the planning of

Manuscript received: $28^{\text {th }}$ May2019

Reviewed: $7^{\text {th }}$ June 2019

Author Corrected: $14^{\text {th }}$ June 2019

Accepted for Publication: $19^{\text {th }}$ June 2019 the disease management. With our self-experience we have noticed that even the educated class of patients are not aware of the complications of Glaucoma. Given that the outreach of the health care system in developing countries remains far from optimal, it is essential that each of the health care providers should be educated about Glaucoma so as to reach a larger sector of the population, which does not have any access to a comprehensive eye care centre.

The present study has been undertaken to evaluate the awareness and knowledge about Glaucoma among hospital personnel.

Objectives- To evaluate the awareness and knowledge about Glaucoma among hospital personnel

\section{Methodology}

Study design: Cross-sectional study

Source of sample: Hospital personnel's working at R L Jalappa Hospital and Research centre, a tertiary care hospital attached to Sri Devaraj Urs Medical College, Tamaka, Kolar. 
Method: After taking an informed consent, a selfdesigned questionnaire about Glaucoma was administered to all the hospital workers. Each questionnaire has two sections: The first section pertaining to information about the participant's demographic characteristics (age, gender, education level, occupation and address).

Section two, pertaining to participant's awareness and knowledge about Glaucoma respectively through a set of questions. All the questions are framed in English as the study is done among educated people. At the end of the study, same interviewers have assessed each of the respondents in terms of their awareness and knowledge associated with Glaucoma.

Inclusion criteria: Medical doctors (Non-ophthalmologists), Nurses, Pharmacists, Physiotherapists, Laboratory staff and administrative staffs.

Exclusion criteria: Patients who have already been diagnosed and are on treatment for Glaucoma were excluded.

Scoring method: Questions answered with a "Yes", "No"\&"Don't know" were scored as 0,1,2 respectively.

\section{Results}

From a total of 513 participants, 138 were males and 375 were females, we received responses to the questionnaire from 150 doctors, 309 nurses, 12 pharmacists, 6 physiotherapists, 6 laboratory staff and 6 administrative staffs and 24 other hospital personnel (CHART 1). Mean age of participants were found to be 34.36+/-5.686.

$95 \%$ were aware of Glaucoma. Only $60 \%$ were aware of the irreversibility of vision and $41 \%$ knew that it will lead to blindness.

$43 \%$ \& $28 \%$ knew that diabetics are more prone for Glaucoma \& steroid instillation can cause Glaucoma respectively. This study showed that there is less knowledge regarding treatment of Glaucoma \& only $29 \%$ were aware that periodic follow-up is necessary in treating Glaucoma.

\begin{tabular}{|c|c|c|c|c|c|c|}
\hline Glaucoma Questionnaire & $\begin{array}{l}\text { Saying } \\
\text { Yes }\end{array}$ & $\%$ & $\begin{array}{l}\text { Saying } \\
\text { no }\end{array}$ & $\%$ & $\begin{array}{c}\text { Saying } \\
\text { don't know }\end{array}$ & $\%$ \\
\hline Have u heard of Glaucoma? & 488 & 95.12 & 17 & 3.31 & 8 & 1.55 \\
\hline $\begin{array}{l}\text { Glaucoma- increased pressure in the } \\
\text { eye, affects vision, Collection of fluid }\end{array}$ & 470 & 91.61 & 28 & 5.45 & 15 & 2.92 \\
\hline $\begin{array}{l}\text { Do you know that Glaucoma can run } \\
\text { in families? }\end{array}$ & 433 & 84.4 & 60 & 11.69 & 20 & 3.89 \\
\hline $\begin{array}{l}\text { Does Glaucoma affect only old } \\
\text { people? }\end{array}$ & 375 & 73.09 & 113 & 22.02 & 25 & 4.87 \\
\hline $\begin{array}{l}\text { Do you that Glaucoma can affect small } \\
\text { babies? }\end{array}$ & 367 & 71.5 & 124 & 24.17 & 22 & 4.28 \\
\hline $\begin{array}{l}\text { Does Glaucoma lead to irreparable } \\
\text { damage to vision? }\end{array}$ & 311 & 60.60 & 169 & 32.94 & 33 & 6.43 \\
\hline Can Glaucoma lead to blindness? & 211 & 41.13 & 253 & 49.31 & 39 & 9.56 \\
\hline $\begin{array}{l}\text { Do you know that diabetics are more } \\
\text { prone for Glaucoma? }\end{array}$ & 224 & 43.66 & 197 & 38.40 & 92 & 17.9 \\
\hline $\begin{array}{l}\text { Do you know that Glaucoma can be } \\
\text { operated? }\end{array}$ & 199 & 38.79 & 214 & 41.71 & 100 & 19.4 \\
\hline $\begin{array}{l}\text { Do you know that laser treatment can } \\
\text { be given for Glaucoma? }\end{array}$ & 187 & 36.45 & 225 & 43.85 & 101 & 19.6 \\
\hline $\begin{array}{l}\text { Do you periodic follow up is necessary } \\
\text { in treating Glaucoma? }\end{array}$ & 148 & 28.84 & 215 & 41.91 & 148 & 28.8 \\
\hline $\begin{array}{l}\text { Do you know that steroid instillation } \\
\text { can cause Glaucoma? }\end{array}$ & 147 & 28.65 & 170 & 33.13 & 194 & 37.8 \\
\hline
\end{tabular}




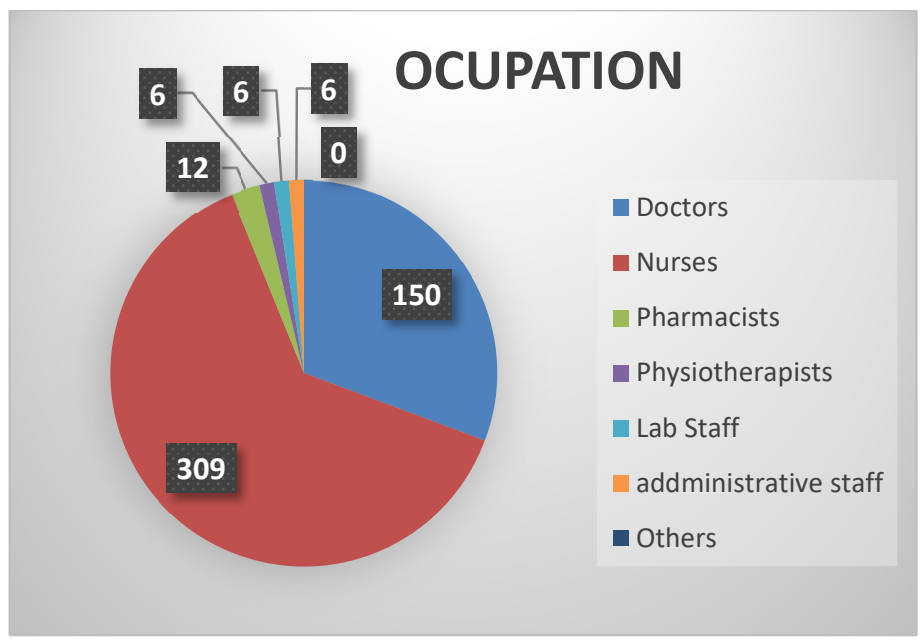

Chart 1

\section{Discussion}

This study was conducted to assess the awareness and knowledge about Glaucoma among hospital personnel in a tertiary care centre of rural Karnataka. The intention of this study was to evaluate the understanding about the nature of Glaucoma and the importance of screening as it has a subtle clinical course leading to irreversible loss of vision.

A large number of participants had heard about the term Glaucoma. There was no relationship found between age or gender and Glaucoma awareness [6,7]. However, this relationship has been noted previously between Glaucoma awareness and a particular gender or age [8$10]$.

A study done by Tenkir et al observed that awareness of Glaucoma in the population is very low. An efficient information, education and communication (IEC) strategy should be undertaken to increase knowledge of Glaucoma so that the early diagnosis and treatment of these individuals under this situation may be possible [6].

Other study by Sathyamangalam et alalso found that Awareness and Knowledge about glaucoma was very low among the urban population of Chennai. Younger subjects who were aware of glaucoma were very less. Subjects with lower levels of education were less aware and knew less about glaucoma than their counterparts. This showed the need for health education for effective blindness prevention due to glaucoma.9

In our study, awareness and knowledge was better among participants with higher elementary education, similar to other awareness prevalence studies $[7,11]$.
This observation signified the importance of education for awareness about the disease.

(91.61\%) of the participants knew that Glaucoma is due to increased IOP and it affects vision. In that the majority who were aware that Glaucoma causes visual defect were doctors. Thereby this study proves the need for health education among the hospital personnel along with general population on a periodic basis, as these hospital personnel may be the first contact to general population. In a study by Lau et al [12], 10\% of the participants were aware about the symptom aspect of Glaucoma. Lack of awareness could often lead to under-diagnosis and late presentation, as noted in several previous studies $[13,14]$.

Another concern was that very few persons (60.6\%) knew about the irreversible nature of visual loss in Glaucoma. Similar trends were noted in many other studies $[6,8]$.

Even the knowledge of diabetes and family history of Glaucoma as risk factors for Glaucoma was high. But the knowledge of corticosteroid as a risk factor was low (28.65\%). One of the studiesfound that $31.7 \%$ thought family history to be a strong risk factor but $26.7 \%$ had no knowledge of risk factors for Glaucoma [15].

This study showed that there is less knowledge regarding treatment of Glaucoma \& only $29 \%$ were aware that periodic follow-up is necessary in treating Glaucoma.

The findings of our study shed light on the level of awareness and knowledge about Glaucoma among 


\section{Original Research Article}

hospital personnel. Awareness about Glaucoma can lead to early detection, a very important step in preventing Glaucoma-related blindness. Similarly educating masses will offer a promise of improving awareness.

What this study adds to existing knowledge? Glaucoma is next to cataract in causing blindness. In our study we found that though there is good awareness among the hospital personnel about glaucoma, the knowledge about it was limited.

As we doctors are restricted to our speciality, it is so frightening that we are unaware of the common conditions which cause irreversible damage in other parts of our body, in spiteof being in hospital atmosphere and in close contact with patients. Therefore, regular awareness programs in the form of lectures, pamphlets, screening camps, etc have to be conducted for all hospital personnel (doctors and nonmedical staffs).

\section{Conclusion}

Though this study shows very good awareness regarding Glaucoma among hospital personnel, the knowledge regarding its causes, associations, treatment and complications were limited.

Among the hospital personnel only the doctors were found to have higher knowledge regarding Glaucoma. It is, therefore, important to emphasize on intensive eye health education and information dissemination, especially among health care professionals.

Educating hospital personnel about the presentation and outcome of this 'silent thief of sight' can be an important step toward preventive ophthalmic care. Continuing medical education about Glaucoma symptoms and subsequent visual impairment, therefore, must be a priority when designing programs for community outreach.

\section{Contribution by authors}

Concept \& Study design: Dr. M S Padmajothi, Dr, Chaitra MC

Questionnaire preparation: Dr. M S Padmajothi

Interviewers: Dr. M S Padmajothi, Dr, Chaitra MC, Dr.Anneshi R C

Statistical analysis and interpretation: Dr. $\mathrm{M} S$ Padmajothi, Dr, Chaitra MC, Dr.Anneshi R C

Manuscript preparation: Dr. M S Padmajothi, Dr, Chaitra MC, Dr.Anneshi R C.
Funding: Nil, Conflict of interest: Nil

Permission from IRB: Yes

\section{References}

1. Resnikoff S, Pascolini D, Etya'ale D, et al. Global data on visual impairment in the year 2002. Bull World Health Organ. 2004 Nov; 82 (11): 844-51. Epub 2004 Dec 14. DOI:/S0042-96862004001100009

2. George R, Ve RS, Vijaya L. Glaucoma in India: estimated burden of disease. J Glaucoma. 2010 Aug;19 (6): 391-7. doi: 10. 1097/ IJG.0b 013e3181 c4 ac $5 b$.

3. Quigley HA, Broman AT. The number of people with glaucoma worldwide in 2010 and 2020. Br J Ophthalmol. 2006Mar;90 (3): 262-7. DOI:10.1136/ bjo. 2005. 081224

4. Vijaya L, George R, Baskaran M, et al. Prevalence of primary open-angle glaucoma in an urban south Indian population and comparison with a rural population. The Chennai Glaucoma Study. Ophthalmology. 2008 Apr; 115 (4): 648-654.e1. Epub 2007 Jul 30. DOI:10.1016/j. ophtha. 2007.04 .062

5. Oliver JE, Hattenhauer MG, Herman D, et al. Blindness and glaucoma: a comparison of patients progressing to blindness from glaucoma with patients maintaining vision. Am J Ophthalmol. 2002 Jun;133(6): 764-72.

6. Tenkir A, Solomon B, Deribew A. Glaucoma awareness among people attending ophthalmic outreach services in Southwestern Ethiopia. BMCOphthalmol. 2010;10:17. doi: 10.1186/1471-2415-10-17.

7. Hennis A, Wu SY, Nemesure B, et al. Awareness of incident open-angle glaucoma in a population study: the Barbados Eye Studies. Ophthalmology. 2007 Oct;114 (10):1816-21. Epub 2007 Aug 15. DOI:10. 1016/j. ophtha. 2007.06.013

8. Krishnaiah S, Kovai V, Srinivas M, et al. Awareness of glaucoma in the rural population of Southern India. Indian J Ophthalmol. 2005 Sep;53(3):205-8. DOI:10. 4103/ 0301-4738.16685

9. Sathyamangalam RV, Paul PG, George R, et al. Determinants of glaucoma awareness and knowledge in urban Chennai. Indian J Ophthalmol. 2009 Sep-Oct;57 (5): 355-60. doi: 10.4103/0301-4738.55073. 
10. Gogate P, Deshpande R, Chelerkar V, et al. Is glaucoma blindness a disease of deprivation and ignorance? A case-control study for late presentation of glaucoma in India. Indian J Ophthalmol. $2011 \mathrm{Jan}-\mathrm{Feb}$; 59 (1):29-35. DOI:10.4103/0301-4738.73720

11. Saw SM, Gazzard G, Friedman D, et al. Awareness of glaucoma, and health beliefs of patients suffering primary acute angle closure. Br J Ophthalmol. 2003 Apr; 87 (4):446-9. DOI:10.1136/bjo.87.4.446

12. Lau JT, Lee V, Fan D, et al. Knowledge about cataract, glaucoma, and age related macular degeneration in the Hong Kong Chinese population. Br J Ophthalmol. 2002 Oct;86(10):1080-4. DOI:10.1136/ bjo.86.10.1080
13. Adegbehingbe BO, Bisiriyu LA. Knowledge, attitudes, and self care practices associated with glaucoma among hospital workers in Ile-Ife, Osun State,Nigeria.TanzanJ Health Res.2008 Oct;10(4):240-5

14. Komolafe OO, Omolase CO, Bekibele $\mathrm{CO}$, et al. Awareness and knowledge of glaucoma among workers in a Nigerian tertiary health care institution. Middle East Afr J Ophthalmol. 2013 Apr-Jun; 20(2):163-7. doi: 10.4103/ 0974-9233.110609.

15. Ichhpujani $\mathrm{P}$, Bharatiya $\mathrm{S}$, Kataria M, Topiwala $\mathrm{P}$. Knowledge, attitude and self-care practices associated with glaucoma among health personnel in tertiary care centre in north India. J CurrGlauPrac. 2012;6(3):10812.doi: 10.5005/jp-journals-10008-1116.

How to cite this article?

Padmajothi M.S, Chaitra M. C, Anneshi R.C. Awareness and knowledge of glaucoma among hospital personnel in a tertiary care center in rural Karnataka. Trop J Ophthalmol Otolaryngol.2019;4(2):126-130.doi:10.17511/jooo.2019.i02.10 